\title{
POGLĄD KAZIMIERZA TWARDOWSKIEGO NA TEMAT ZAJMOWANIA SIĘ PRZEZ FILOZOFIĘ "POGLĄDAMI NA ŚWIAT I ŻYCIE" KILKA SŁÓW W KWESTII ROZUMU PRAKTYCZNEGO
}

Przemówienie Kazimierza Twardowskiego wygłoszone w roku 1929 na zebraniu jubileuszowym z okazji ćwierćwiecza utworzenia Polskiego Towarzystwa Filozoficznego zawiera bardzo wiele treści istotnych m.in. z punktu widzenia zastanawiania się nad tym, czym jest filozofia i co może ona sądzić na temat swych zadań, funkcji i kompetencji. Poniższe uwagi zainspirowane są właśnie treściami tego wystąpienia. Szczególnie zaskakujące zdają się stwierdzenia Twardowskiego na temat tak istotnego elementu Kantowskiego systemu filozoficznego, jakim jest niewątpliwie rozum praktyczny. Dlatego też pokantowskim losom Kantowskiego rozumu praktycznego, całkowicie zdezawuowanego przez skądinąd wielce zasłużonego dla polskiej filozofii twórcę Szkoły Lwowskiej - która szybko stała się Szkołą Lwowsko-Warszawską - poświęcone zostaną krótkie uwagi w drugiej części tekstu (2). W pierwszej, głównej części tekstu przedmiotem uwag i namysłu staną się zawarte we wspomnianej przemowie jubileuszowej z roku 1929 stwierdzenia Twardowskiego na temat tego, co nazwane jest "poglądem na świat i życie”, na temat "krytycyzmu”, a także na temat rozumu praktycznego (1).

\section{W kwestii „poglądu na świat i życie”, krytycyzmu oraz rozumu praktycznego}

Kazimierz Twardowski, tłumacząc powody, dla których Polskie Towarzystwo Filozoficzne „wcale nie zajmuje się sprawami poglądu na świat i życie" (1929, s. 17), zauważa, że ktoś mógłby twierdzić, że ,jest to [...] najważniejsza strona wszelkiej należycie pojętej pracy filozoficznej, skoro kształtowaniu takiego [tzn. filozoficznego - A.M.K.] poglądu służyły 
i służą najszczytniejsze wysiłki twórcze największych filozofów wszelkich czasów" (1929, s. 17). Twardowski, jak się zdaje, takie przekonanie też podziela, czyli uznaje, że najtęższe umysły filozoficzne niegdyś zajmowały się jednak „poglądami na świat i życie”. Stwierdza też, że "potrzeba filozoficznego poglądu na świat i na życie budzi się coraz żywiej także w naszem społeczeństwie" (Twardowski 1929, s. 17). Identyfikuje też tych, którzy taką potrzebę zgłaszają: „Sprawa filozoficznego poglądu na świat i na życie jest niewątpliwie doniosłą dla każdego, komu nie wystarcza tradycyjny pogląd religijny, a kto zarazem nie umie patrzeć na świat i kroczyć przez życie bezmyślnie" (Twardowski 1929, s. 18). Jednocześnie jednak wyraża pogląd, że filozofia pragnąca mieć charakter naukowy (a odnosi się to także do stowarzyszenia aspirującego do rangi „towarzystwa naukowego") nie może „zajmować się szerzeniem jakiegokolwiek filozoficznego, to znaczy metafizycznego poglądu na świat i życie" (Twardowski 1929, s. 18).

W związku z tymi stwierdzeniami powstaje pytanie, jakie to okoliczności sprawiają że to, co było niegdyś integralnym przedmiotem filozoficznych dociekań najwybitniejszych umysłów - a co się tu nazywa „poglądem na świat i życie” i co w znacznym stopniu utożsamione jest z uprawianiem metafizyki (bądź „myśleniem religijnym”), a nadto jest też uzasadnioną potrzebą ludzi współczesnych Twardowskiemu - nie może już być przedmiotem ambitnej filozofii, która chce sprostać intelektualnym standardom epoki, ale zarazem nie chce być żadnym systemem metafizycznym ani podbudową dla jakiegoś światoobrazu religijnego. Poglądy na świat i życie, wyobrażenia metafizyczne tudzież wyobrażenia religijne mają być czymś, co według Twardowskiego może być składnikiem prywatnego myślenia ludzi uprawiających akademicko filozofię, ale nie mogą one być przedmiotem filozoficznych dociekań, których celem miałaby być obrona któregokolwiek z tego rodzaju poglądów lub dowodzenie ich prawdziwości, naukowe dowodzenie ich obiektywnej ważności, dające w efekcie możność „,zniewolenia innych do przyjęcia tego poglądu" (Twardowski 1929, s. 24).

Pierwszy wniosek, jaki się nasuwa w związku z powyższymi stwierdzeniami, brzmieć musi następująco: filozofia uprawiana współcześnie, przez co należy w tym wypadku rozumieć również filozofię uprawianą już w czasach Twardowskiego (a także tę przez niego propagowaną), jeśli chce zmierzać - jak to określił też w swym przemówieniu z roku 1904, podczas otwarcia działalności Polskiego Towarzystwa Filozoficznego we Lwowie - „,ku wyświetleniu prawdy” (Twardowski 1904, s. 241), musi być filozofią post-metafizyczną. Drugi z kolei wniosek brzmiałby następująco: według Twardowskiego jedyną wyobrażalną formą wyartykułowania „poglądu na świat i życie”, który mógł byłby się mienić „filozoficznym 
poglądem na świat i życie", jest metafizyka. Rozumowanie Twardowskiego wygląda zaś, ostatecznie, następująco: ponieważ metafizyka - jak to wykazał I. Kant - nie kwalifikuje się do tego, by być nauką, nauką zaś chce być filozofia, a z kolei warunkiem filozoficznego charakteru „poglądu na świat i życie" jest wyartykułowanie go w formie koncepcji metafizycznej, to w konsekwencji oznacza, że filozofia nie może zajmować się czymś takim jak „pogląd na świat i życie”, bo musiałaby zająć się uprawianiem metafizyki, a to by sprawiło, iż przestałaby być filozofią aspirującą do naukowego charakteru.

Rzeczą wymagającą dookreślenia pozostaje oczywiście rozumienie metafizyki przez Twardowskiego Można powiedzieć, że „w połowie" pokrywa się ono z rozumieniem metafizyki przez Kanta, ale tylko „w połowie"; podobnie zreszta, jak i jego rozumienie krytycyzmu też co najwyżej „w połowie” pokrywa się z Kantowskim pojmowaniem krytycyzmu. Kant, z jednej strony, był postrzegany jako der "Alleszermalmer" der Metaphysik, czyli ten, który metafizykę obrócił w perzynę, który obnażył metafizyczne iluzje, a iluzje te to iluzje starej, dogmatycznej, czyli przedkantowskiej metafizyki, która miała się za naukę władną wykraczać poza to, co zjawiskowe, czyli zdolną do poznania - mieniącego się nauką - czy to Boga, czy też duszy, czy też rzeczy samych w sobie. Twardowski, mówiąc o metafizyce, ma na myśli takie jej właśnie rozumienie i zgadza się tu z Kantem, który fundamentalnie zakwestionował aspiracje tejże metafizyki do naukowości. Jednocześnie jednak najgłębszą intencją Kanta, o czym Twardowski już nie wspomina, była obrona metafizyki. Tyle tylko, że chodziło już o inaczej rozumianą metafizykę, rozumianą - przynajmniej gdy chodzi o wiodący temat Krytyki czystego rozumu - jako dociekania zmierzające do wydobycia racjonalnych, czytaj: rozumowych fundamentów poznania $\mathrm{w}$ naukach przyrodniczych. Twardowski to przemilcza, jak też przemilcza to, że wedle Kanta metafizyka - ale oczywiście w tym jej «kantowsko-post-metafizycznym» rozumieniu, jedynym prawomocnym, według Kanta, rozumieniu metafizyki - odsłania również fundamenty moralności. Przez metafizykę rozumie bowiem Kant „filozofię [...] która nauki swe wykłada tylko na podstawie zasad a priori", jest zatem "filozofią czysta" - czyli jest filozofia, która w najmniejszym nawet stopniu nie „opiera się na podstawach doświadczenia" - i która, jako filozofia czysta, występuje albo jako logika, ,jeżeli jest tylko formalna”, albo jako metafizyka, ,jeżeli ogranicza się do pewnych przedmiotów intelektu” (Kant 1953, s. 4). Z takim rozumieniem metafizyki Twardowski już się nie zgadza, nie zgadza się też z takim pojmowaniem „rozumu”, z przypisywaniem mu takich kompetencji, jakie, jak stwierdza, nie są wszak dane „rozumowi w zwykłym tego słowa znaczeniu" (Twardowski 1929, s. 20). Twardowski nie jest gotów zaakceptować tego, czego dokonuje Kant, a mianowicie "transcendentalizacji" rozumu. 
Połowiczna zgoda z Kantem zachodzi też w wypadku rozumienia „krytyki” czy „krytycyzmu”. „Naukowy krytycyzm” - jak to deklarował Kazimierz Twardowski już w przemówieniu z 1904 r. - „powinien nas uchronić od wszelkich uprzedzeń i formułek, z góry narzuconych lub dobrowolnie przyjętych"; ówże duch krytycyzmu winien przeniknąć wszelkie prowadzone badania filozoficzne; biorąc ",sobie za hasło unicestwienie dogmatyzmu filozoficznego", pójdziemy w ślady Kanta, deklaruje w swej przemowie Twardowski:

[...] praca jego życia [chodzi oczywiście o Kanta - A.M.K.] starczy także nam za hasło i program. Zgodnie z jego żądaniem, będziemy zawsze usiłowali zdawać sobie sprawę z podstaw, na których się nasze twierdzenia i poglądy opierają (1904, s. 242).

Ten krytycyzm, którego rzecznikiem jest Twardowski - ów „krytycyzm naukowy" - z pozoru tylko jest w duchu Kantowskim. Wprawdzie twórca Szkoły Lwowskiej uczciwie zastrzega, że „[n]ie będziemy [...] wyznawać niewolniczo wszystkich poglądów Kanta", jednak w istocie to, co pozostaje z poglądów Kanta, to jedynie hasła: „nie” dla metafizyki - a należy to zapewne rozumieć: wszelakiej metafizyki, również tej, która jest metafizyką tworzoną przez Kanta i którą można nazwać „metafizyką ztranscendentalizowanego rozumu” - "tak” natomiast dla krytycyzmu, który ustrzec ma przed "pozorami naukowości” (Twardowski 1904, s. 242). Ale i akceptacja tego krytycyzmu nie jest w istocie akceptacją Kantowskiego krytycyzmu. Dlaczego winniśmy raczej mówić $\mathrm{w}$ wypadku "krytycyzmu” o powierzchownym tylko, w istocie pozornym powinowactwie "krytycyzmu” Twardowskiego z "krytycyzmem” Kanta, skutkującym dalszymi, daleko idącymi rozbieżnościami? Powód jest prosty i można to wyczytać $\mathrm{z}$ hasłowych opracowań, które zapewne też były dobrze znane Twardowskiemu, jak np. Rudolfa Eislera Wörterbuch der philosophischen Begriffe und Ausdrücke z 1899 r. Po zwięzłym, wprowadzającym i ogólnikowym stwierdzeniu, iż „,[p]rzez krytycyzm rozumie się od czasów Kanta wszelki kierunek filozoficzny, który czyni teorię poznania podstawą wszelkiego filozofowania, w szczególności zaś naukę samego Kanta" (Eisler 1899, s. 422), przytoczony jednak zostaje przez Eislera fragment Krytyki czystego rozumu charakteryzujący to, co uznać należy za drugi aspekt tej integralnej Kantowskiej całości, na którą składa się wszelako nie tylko „krytycyzm”, ale też i „transcendentalizm”, będący konsekwencją dokonanego przez Kanta, jak to sam określił, „kopernikańskiego przewrotu”"1.

${ }^{1}$ Pod hasłem „Kriticismus”, bezpośrednio po zacytowanych wyżej słowach, ogólnie mówiących, czym jest krytycyzm, zostaje w słowniku Eislera z roku 1899 przytoczony ten znany dobrze fragment z Krytyki czystego rozumu: „Dotychczas przyjmowano, że wszelkie nasze poznanie musi się dostosowywać do przedmiotów. Lecz wszelkie próby, by o nich 
W wydaniu trzecim, całkowicie na nowo opracowanym słowniku Eislera - który zapewne musiał też być znany Twardowskiemu - hasło „krytycyzm" jest nie tylko o wiele bardziej obszerne, ale i już na samym początku przedstawienia krytycyzmu o wiele bardziej precyzyjnie scharakteryzowany zostaje podstawowy jego sens jako stanowiska filozoficznego i jako określonej metody, których twórcą był Kant, a których nie sposób poprawnie rozumieć, jeśli abstrahuje się od Kantowskiego "transcendentalizmu". W tym wydaniu słownika Eislera czytamy:

Krytycyzm to: punkt widzenia krytyki, filozoficzno-krytycznego, transcendentalnego, teoriopoznawczego postępowania jako metody, polegającej na poddawaniu - poprzedzającym wszelką pozytywną filozofię (metafizykę itd.) - systematycznemu sprawdzeniu możliwość, zgodność z pewnym prawidłem [Gesetzmäßigkeit], źródło, prawowitość oraz granice ludzkiego poznania, nieprzyjmowaniu niczego w sposób dogmatyczny, lecz poddawaniu analizie pojęć i sądów, wyprowadzania ich z tego, co jest ich "fundamentem" oraz oceniania ich pod kątem ich logicznej poprawności i prawomocności („metoda krytyczna” [kritische Methode]). W węższym sensie krytycyzm to bazująca na Kantowskiej krytyce rozumu kontynuacja prac nad teorią poznania i nad światooglądem [Weltanschauung] (Eisler 1910, s. 679-680).

Twardowski postawił wprawdzie Kanta na piedestale, widząc w nim - kiedy to dokładnie w setną rocznice jego śmierci przemawiał podczas uroczystości otwierającej działalność Polskiego Towarzystwa Filozoficznego - „męża, który więcej aniżeli ktokolwiek inny, przyczynił się do tego, że duch naukowego krytycyzmu przenikać zaczął badania filozoficzne" (Twardowski 1904, s. 242); jednocześnie jednak uznał za nieważne - a nawet, jak się zdaje, za szkodliwe - te fundamentalne elementy myśli Kanta, na których się zasadza jej specyfika i które stanowiły i stanowią o jej doniosłości, a takim elementem jest, będący następstwem „kopernikańskiego przewrotu", transcendentalizm.

Można zapewne, do pewnego stopnia, zrozumieć niechęć Twardowskiego do transcendentalizmu, gdyż efekty pośredniego jego oddziaływania na polską myśl, skutkującego, jak to nazwie, „bujaniem w obłokach", nie przyczyniły się raczej do dalszego rozwoju myśli filozoficznej w Polsce. W wypadku tej rzeczonej niechęci chodzi o transcendentalizm,

przy pomocy pojęć orzec coś, co by rozszerzało poznanie nasze, obracały się przy tym założeniu w niwecz. Spróbujmy więc raz, czy nam się lepiej nie powiedzie przy rozwiązywaniu zadań metafizyki, jeżeli przyjmiemy, że to przedmioty muszą się dostosowywać do naszego poznania. Zgadza się to już lepiej z wymaganą możliwością poznawania ich a priori, które ma coś ustalić o przedmiotach, zanim nam one są dane. Rzecz się z tym ma tak samo, jak z pierwszą myślą Kopernika, który, gdy wyjaśnianie ruchów niebieskich nie chciało się udawać przy założeniu, że cała armia gwiazd obraca się dookoła widza, spróbował, czy nie uda się lepiej, jeżeli każe się obracać widzowi, natomiast gwiazdy pozostawi w spokoju" (Kant 1957, s. 30-31 [B XVI]). 
mimo że sam ten termin w przywołanych mowach Twardowskiego nie pada. Nie da się jednak temu zaprzeczyć, że o niego to przede wszystkim Twardowskiemu chodzi², kiedy w wystąpieniu z roku 1904 mówi o „niemieckiej filozofii pokantowskiej" (Twardowski 1904, s. 242). Można się też zgodzić ze sformułowaną w tym samym wystąpieniu oceną: „W rozwoju polskiej filozofii bezpośredni wpływ Kanta zaznaczył się bardzo słabo" (Twardowski 1904, s. 242). Wpływ pośredni miał być natomiast znaczniejszy, chociaż w sumie losy i konsekwencje tych oddziaływań nie zasłużyły na pochwałę ze strony Mówcy:

Najświetniejsze chwile rozwoju filozofii w Polsce pozostawały pod wpływem niemieckiej filozofii pokantowskiej, która wzięła od Kanta wiele pomysłów, ale nie przejęła się jego duchem krytycznym. I dlatego wyrodziła się w niesłychany dogmatyzm - i upadła. A filozofia polska, wydawszy pod jej wpływem niemniej świetne od niej blaski, również upadła (Twardowski 1904, s. 242).

Twardowski wypowiada się tu zapewne na temat oddziaływania na polską myśl XIX w. filozofii G.W.F. Hegla, kiedy krytykując nastały po tym okresie oddziaływania idealizmu niemieckiego "nieco powierzchownie pojęty pozytywizm”, widzi w nim reakcję „na poprzednie dogmatyczne bujanie w obłokach" (1904, s. 242). Ta era pozytywizmu, która uznana przezeń została za epokę zastoju, nastąpiła „,[p]o wielkim bogactwie konstrukcji i spekulacji filozoficznych" (1904, s. 242), jednakże błędem, zdaniem Twardowskiego, było „ślep[e] odda[nie] w niewolniczą służbę niemieckiej filozofii idealistycznej" (1904, s. 242). Z tą oceną wypada zapewne się zgodzić. Jednym z remediów na tego rodzaju błąd miałoby być, według Mówcy, równomierne czerpanie impulsów z dokonań trzech głównych filozofujących nacji: zarówno Niemców, jak też Anglików i Francuzów ${ }^{3}$. I o ile na proponowane tu remedium można się zgodzić, o tyle jednak inne budzić musi poważne zastrzeżenia.

${ }^{2}$ Wprawdzie termin "transcendentalizm" nie pada, ale wypowiadane krytyczne sądy o filozofii Kanta i formułowane na jej temat oceny są w pełni zbieżne z sądami i ocenami, jakie po bliższym nieco, krytycznym omówieniu Kantowskiej koncepcji „sądów syntetycznych a priori” - czyli głównej „technicznej” kwestii Kantowskiego transcendentalizmu - formułuje F. Brentano, por. (Brentano 1895, s. 24-27). Wyraźnie za tymi jego wywodami podąża Twardowski w swoich obydwu mowach, w pełni też akceptuje wyprowadzane przez Brentano konkluzje. Różnica w stosunku do Brentano polega zaś na tym, że w odróżnieniu od swego mistrza - podczas studiów Twardowskiego w Wiedniu Brentano „stał się jego ulubionym profesorem” (Kleszcz 2013, s. 12) - Twardowski z ogromną estymą wypowiada się o Kancie jako twórcy krytycyzmu, podkładając jednak - jak już to zostało wyżej powiedziane - pod Kantowskie pojęcie „krytyki” swoje własne rozumienie tego terminu i winnej kryć się za tym terminem procedury.

3 "Nie powinniśmy ulegać jednostronnie wpływowi tego lub owego kierunku, ani nawet tego lub owego narodu. Naszymi przewodnikami nie powinni być ani Anglicy, ani Francuzi, ani Niemcy wyłącznie, lecz wszyscy razem" (Twardowski 1904, s. 242). 
Owo „dogmatyczne bujanie w obłokach" nie stało by się przypadłością polskiej myśli poddanej pośrednim wpływom myśli Kanta, gdyby polska filozofia czerpała bezpośrednio z Kanta i oczywiście inaczej zupełnie, aniżeli uczynili to kontynuatorzy Kanta sytuujący się w nurcie «niemieckiej filozofii idealistycznej». Przed popadnięciem «w niewolniczą służbę niemieckiej filozofii idealistycznej» i przed nastaniem tego „smutn[ego] stan[u] rzeczy" mógł był, zdaniem Twardowskiego, naszą myśl filozoficzną uchronić "duch Kanta przemawiający z pism Jędrzeja Śniadeckiego, Jarońskiego i innych" (Twardowski 1904, s. 242). Powołanie się na tego pierwszego rodzimego komentatora filozofii Kanta nie wystawia tu jednak zbyt dobrego świadectwa powołującemu się na niego Mówcy. Śniadecki, gdy chodzi o zrozumienie myśli Kanta, wykazał się daleko idącym zadufaniem i ograniczonymi zdolnościami rozumienia, ale to on zdaje się - w opinii Twardowskiego - tym prawdziwym obrońcą rozumu „w zwykłym tego słowa znaczeniu"4.

Z innych wprawdzie powodów niż w wypadku Śniadeckiego, ale duży sprzeciw budzi też i u Twardowskiego mówienie przez Kanta o Bogu i duszy. Dla Śniadeckiego jest niepojęte, jak o Bogu można mówić jako o formie rozumu, dla Twardowskiego natomiast jest niepojęte, jak w ogóle można mówić o Bogu w ramach filozofii, która ma być filozofią naukową. Powodem, dla którego, według Twardowskiego, Kant mówi o Bogu, jest zupełnie nieprzystająca do standardów filozofii naukowej chęć wyartykułowania przezeń "filozoficznego poglądu na świat i życie" oraz zupełnie nietrafny sposób obrony przez popadnięciem w sceptycyzm.

Wbrew duchowi swej własnej filozofii, tak zdaje się sądzić Twardowski, czyli wbrew naukowemu krytycyzmowi, Kant chce udzielić ostatecznej odpowiedzi na „zagadnienia sięgające istoty człowieka, początku i celu wszelkiego bytu oraz przeznaczenia człowieka" (Twardowski 1929,

${ }^{4}$ Ilustracją stopnia zrozumienia przez Śniadeckiego Kantowskiej Krytyki czystego rozumu mogą być oceny, jakie sformułował po tym, jak w kilku słowach przedstawił odróżnienie, którego Kant miałby dokonać, na umysł empiryczny oraz umysł czysty, wspominając przy tym o mnóstwie form, które Kant nazwał kategoriami: „[t]ym podziałom i formom ponadawał nazwiska: stąd powstała jego nomenklatura ciemna, zagmatwana i niepoięta: a z nich cała nauka słów niezrozumiałych: gdzie umysł utopiony i obłąkany w przesadzonych abstrakacyach, nic iaśnie ani nie widzieć, ani poymować nie może. Któżto poymie że czas i przestrzeń (spatium) są formami czucia: że Bóg, dusza ludzka, i świat powszechny są formami rozumu itd. Z tymto konceptem prawdziwie mistycznym uważając wrażenia zmysłowe iako pozory, wpada koniecznie w Idealizm: zasadzaiąc znowu wszelką pewność na iakichsi początkach i prawach rozumowi wlanych, wpada w dogmatyzm: i cała nauka Krytycizmu (iak ią nazwał Kant) nic innego nie iest, tylko dawne szkolne dziwactwa, i przesadzone spekulacye, ubrane w ięzyk tak ciemny i prawdziwie barbarzyński: że ciemnotą i zawrotem głowy wszystkie dawne marzenia przewyższył. Kto się ciemno tłumaczy, ten się sam nie rozumie, albo sili się na zrozumienie tego, co iest do poięci niepodobne" (Śniadecki 1821, s. 22-23). 
s. 18). Krytycyzm naukowy nie pozwala jednak, twierdzi Kazimierz Twardowski, na „przyj[mowanie] i szerzeni[e] poglądów roszczących sobie pretensję, że zawierają ostateczną odpowiedź na najtrudniejsze zagadnienia, które się człowiekowi narzucają" (Twardowski 1929, s. 18). A „,[c]zyż można - pyta retorycznie - jakąkolwiek odpowiedź na takie zagadnienie metodami naukowemi uzasadnić, przy pomocy argumentacji logicznej uprawdopodobnić?" (Twardowski 1929, s. 18-19).

Powodem, dla którego Kant - wbrew swoim własnym ustaleniom, zgodnie z którymi żadnej wiedzy, żadnego poznania w sprawach Boga tudzież w sprawach duszy, być nie może - nie uznał, że kwestie te w ogóle sytuują się poza obszarem naukowej filozofii i poza obszarem poznania, było to, iż będąc poniekąd obciążonym metafizycznym myśleniem, obawiał się popadnięcia w sceptycyzm. Przed tym ostatnim miał go, jak to interpretuje Twardowski, ratować pomysł mówienia o jakimś innym rozumie, różnym od rozumu teoretycznego: „odmówiwszy rozumowi w zwykłym tego słowa znaczeniu zdolności znalezienia poglądu na świat i życie, przyjął obok owego rozumu, który nazwał teoretycznym, jakiś drugi rozum, zwany przezeń praktycznym" (Twardowski 1929, s. 20). Tenże rozum miałby być źródłem owej pewności poszukiwanej przez pragnących uzyskać definitywną odpowiedź na „,zagadnienia sięgające istoty człowieka, początku i celu wszelkiego bytu oraz przeznaczenia człowieka” (Twardowski 1929, s. 18), czyli pragnących posiadać „filozoficzny pogląd na świat i życie”. Ów "rozum praktyczny”, porównywany przez Twardowskiego do Platońskiego «oglądania idei», czy Plotyńskiej «ekstazy» jest według niego - takim samym, jak «ogląd intelektualny» czy «intuicja» - „nierozumow[ym] źródł[em] przekonań” (Twardowski 1929, s. 20). Są to wszystko źródła, które leżą według Twardowskiego poza rozumem, a więc w konsekwencji „przekonania $\mathrm{z}$ ich czerpane będą nierozumowe czyli irracjonalne, a tem samem przekonania te, o ileby nawet tworzyły wiedzę, nie będą miały charakteru naukowego ani owa wiedza nie będzie nauką" (Twardowski 1929, s. 21). Właściwe stanowisko w kwestii tychże przekonań miał według Twardowskiego, sądząc z wytaczanych argumentów, David Hume, który odmawiał rozumowi władzy orzekania o tym, co jest dobre, a co złe, co jest słuszne, a co niesłuszne. W wypadku przekonań, twierdzi Twardowski, nie ma „miejsca na argumentowanie - tu można nieprzekonanemu powiedzieć jedynie «Patrz» albo «Czuj» a kto patrząc nie widzi albo kto nie czuje, nad tym można ubolewać, ale przekonać nie podobna" (Twardowski 1929, s. 21).

Ostatnim słowem filozofii, tej właśnie postmetafizycznej i aspirującej do naukowego charakteru, a taką wszak chce ją widzieć Twardowski, jest wyrzeczenie się jakiegokolwiek zabierania głosu w sprawach tyczących poglądów na świat i życie. Jest to m.in. konsekwencją zakwestionowania 
filozoficznej prawowitości - obecnemu wszak w konstrukcjach filozoficznych od Arystotelesa, przez Tomasza z Akwinu, po Kanta - „rozumowi praktycznemu". Oprócz widomej filozoficznej powściągliwości sprawia takie rozwiązanie, iż zablokowany został właściwie pewien możliwy tor rozwoju myśli filozoficznej, po którym kroczyć mogła i może jedynie myśl akceptująca dokonany przez Kanta przewrót w filozofii, opowiadająca się za transcendentalizmem $\mathrm{w}$ takiej bądź innej postaci.

\section{Zakończenie. Kilka słów o pokantowskich losach rozumu praktycznego}

Ścieżką wskazaną przez Twardowskiego, którą krocząc, filozofia winna zachować całkowitą powściargliwość w wypowiadaniu się w kwestiach "poglądów na świat i życie", jak też zrezygnować z roszczenia do rozumowego ugruntowania roszczeń normatywnych, nie poszła jednak cała filozofia. Po okresach płytkości, o której wspominał Twardowski, mówiąc o pewnych nurtach filozofii dziewiętnastowiecznej, nastały czasy, w których zarówno szeroko dyskutowano nad transcendentalizmem, nad roszczeniami rozumu praktycznego, jak i nad filozoficznym ogarnięciem fenomenu epoki po-metafizycznej, z jakim filozofia Twardowskiego nie próbowała się zmierzyć, a mianowicie fenomenu, jakim jest pluralizm "poglądów na świat i życie".

Twardowski niewątpliwie trafnie diagnozuje sytuację współczesna, oceniając ją jako sytuację po-metafizycznego myślenia. Nie dostrzega jednak tego - było być może na to za wcześnie, albo też jednak pewien antytranscendentalistyczny przed-sąd mu na to nie pozwolił - iż zapoczątkowany przez Kanta proces rozstawania się z metafizycznymi obrazami świata, czyli przechodzenia do myślenia po-metafizycznego, jest zarazem procesem transformowania "Kantowskiego rozumu”, to znaczy rozumu stranscendentalizowanego. Jest to proces, w którym transformacji ulega pojmowanie "rozum praktycznego". Oczywiście Kantowski rozum praktyczny - a zatem rozum pomyślany już po „kopernikańskim zwrocie” - jest nie taką samą władzą, jaką był dla Arystotelesa czy Tomasza z Akwinu. Jest to rozum czynny, rozum prawodawczy (co dla Śniadeckiego, jak świadczą o tym jego stwierdzenia na ten temat, było czymś nie do pojęcia), a zarazem rozum transcendentny $w$ tym sensie, iż jest rozumem dyktującym działaniu w świecie empirycznym pewną normę, niemniej jednak jest od tego świata empirycznego rozumem całkowicie niezależnym ${ }^{5}$.

${ }^{5}$ Problematyka ta i wszelkie rozważania prowadzone na ten temat - „w odnośnej literaturze niemieckiej” - były też dalece niezrozumiałe dla Marii Ossowskiej, uczennicy Tadeusza Kotarbińskiego, a przez to pośrednio uczennicy Twardowskiego. Pisząc o proble- 
Ten stranscendentalizowany rozum - który przed Kantowskim „przewrotem kopernikańskim" był po prostu rozumem wpisanym w porządek bytu bądź $\mathrm{w}$ tożsamy $\mathrm{z}$ nim porządek stworzenia - poddany następnie zostaje detranscendentalizacji. Proces ten wiódł od zdetranscendentalizowanego przez Hegla rozumu praktycznego, przekształconego przezeń w „ducha obiektywnego", poprzez „ujęzykowienie” owego ducha obiektywnego (co było dokonaniem m.in. Wilhelma von Humboldta ${ }^{6}$ ), jak też w wyniku zwrócenia się ku „praktyce” - ku pracy bądź ku działaniu społecznemu, bądź też ku komunikacji - co dokonało się za sprawą zarówno Marksa, jak i amerykańskiego pragmatyzmu, przede wszystkim Charlesa Sandersa Peirce'a - i co wiodło następnie do socjologicznych teorii działania, do ontologizacji językowości (Hans-Georg Gadamer), a ostatecznie: do teorii racjonalności komunikacyjnej.

Właśnie teoria racjonalności komunikacyjnej jest taką transformowaną postacią zdetranscendentalizowanego rozumu praktycznego, który ma swoje osadzenie nie w jednostkowym podmiocie, tylko w intersubiektywności, której integracja i funkcjonowanie są możliwe tylko dzięki czynieniu zadość pewnym normatywnym roszczeniom - roszczeniom „rozumu komunikacyjnego".

Jest to już jednak koncepcja, której należy poświecić odrębnie uwagę. W świetle rekonstruowanych tu poglądów Twardowskiego koncepcja racjonalności komunikacyjnej jawi się jako interesująca $z$ tego przede wszystkim względu, iż akceptując pluralizm „poglądów na świat i życie", dostarcza także miar mogących posłużyć partycypującym w takiej pluralistycznej rzeczywistości do stwierdzania, na ile dokonywane rozstrzygnięcia normatywne mogą być przez nich uznane za akceptowalne a to znaczy: poparte racjami. Warunkiem afirmacji tychże "racji” jest jednak przejście w myśleniu od postrzegania rzeczywistości przez pryzmat "obrazów świata" do jego postrzegania przez pryzmat „świata życia” - czyli przejście od myślenia w kategoriach wyznaczonych przez Weltbild do myślenia w kategoriach wyznaczonych przez Lebenswelt, albowiem to „światu życia" immanentna jest postmetafizycznie pojmowana rozumność, czyli „racjonalność komunikacyjna”.

matyce norm i poświęconej temu literaturze - której autorami w przeważającej mierze zdają się być prawnicy - czyni Ossowska na samym wstępie następujące uwagi: „Próbki tych wypowiedzi nie są na ogół, przyznać trzeba zachęcające, przywykło się bowiem, zwłaszcza w odnośnej literaturze niemieckiej, wytwarzać dookoła sprawy normy atmosferę takiego patosu, że tłumaczenie tych górnych enuncjacji na prosty i zrozumiały język zabiera bardzo wiele czasu i co gorsza po to tylko, żeby okazać się w rezultacie nader mało wydajne. Nieliczni pisarze usiłujący sprawę ściągnąć z nieba na ziemię słusznie, jak się zdaje, przypisywali Kantowi niemały udział w zamąceniu zagadnienia. Od patetycznego tonu, w jakim Kant mówił o das Sollen, mało kto odważył się po nim odstąpić" (Ossowska 1957, s. 126).

${ }^{6},[\ldots]$ so liegt in jeder Sprache eine eigenthümliche Weltansicht" (Humboldt 1836, s. 58). 


\section{Bibliografia}

Brentano F. (1895), Die vier Phasen der Philosophie und ihr augenblicklicher Stand, Verlag bei J. G. Cotta'schen Buchhandlung, Stuttgart, s. 24-27.

Eisler R. (1899), Kriticismus, [w:] idem, Wörterbuch der philosophischen Begriffe und Ausdrücke, Ernst Siegfried Mittler und Sohn, Berlin, s. 422-423.

Eisler R. (1910), Kritizismus, [w:] idem, Wörterbuch der philosophischen Begriffe, Ernst Siegfried Mittler und Sohn, Berlin, s. 679-683.

Humboldt W. v. (1836), Über die Verschiedenheit des menschlichen Sprachbaues und ihren Einfluss auf die geistige Entwickelung des Menschengeschlechts, Dümmler, Berlin.

Kant I. (1953), Uzasadnienie metafizyki moralności, PWN, Warszawa.

Kant I. (1957), Krytyka czystego rozumu, t. 1, PWN, Warszawa.

Kleszcz R. (2013), Metoda i wartości. Metafilozofia Kazimierza Twardowskiego, Wydawnictwo Naukowe Semper, Warszawa.

Ossowska M. (1957), Podstawy nauki o moralności, PWN, Warszawa.

Śniadecki J. (1821), Pisma Jana Śniadeckiego o filozofii Kanta, Druk Uniwersytetu Jagiellońskiego, Kraków.

Twardowski K. (1904), Otwarcie Polskiego Towarzystwa Filozoficznego we Lwowie, „Przegląd Filozoficzny" 7, 2, s. 239-243.

Twardowski K. (1929), Przemówienie prof. dra Kazimierza Twardowskiego wygłoszone na zebraniu jubileuszowym Polskiego Towarzystwa Filozoficznego dnia 12. Lutego 1929 r., nakładem „Słowa Polskiego", Lwów.

Streszczenie: Poglad Kazimierza Twardowskiego na temat zajmowania sie

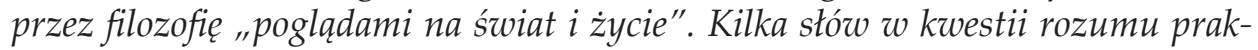
tycznego

Na losach „filozofii praktycznej" w Polsce zaważyły w znacznej mierze poglądy Kazimierza Twardowskiego. Ten mający ogromne zasługi dla polskiej filozofii uczeń Franza Brentano był z jednej strony wielkim admiratorem Kanta, a z drugiej całkowicie dezawuował jego koncepcję rozumu praktycznego. Powodem admiracji było to, że Kant odebrał metafizyce (w jej ówczesnym i niegdysiejszym rozumieniu) prawo do tego, by się mogła mieć za naukę, od myślenia filozoficznego zaś domagał się przejścia na pozycje krytycyzmu. Twardowski zdał się jednak pominąć całkowicie to, że Kantowskiego krytycyzmu nie można oderwać od - będącego jego drugą stroną - Kantowskiego transcendentalizmu. Wprawdzie $\mathrm{w}$ pewnym nurcie kontynuacji kantowskiego transcendentalizmu w filozofii niemieckiej, a także u jej polskich twórczych kontynuatorów doszło do „dogmatycznego bujania w obłokach”, nie jest to jednak jeszcze dostateczny powód, by rozstać się z rozumem praktycznym i zgodzić się z Twardowskim, który twierdzi, iż w gestii filozofii nie leży zajmowanie się „poglądami na świat i życie”. Takie m.in. poglądy na temat spraw, którymi zajmował się od wieków "rozum praktyczny”, przyczyniły się do powstania w polskiej filozofii luki w namyśle nad możliwością 
rozprawiania $\mathrm{w}$ ramach filozofii nad sprawami związanymi z poglądem na świat i życie. Namysł taki prowadzony był natomiast w filozofii niemieckiej (w wyniku przekształcenia przez Hegla "rozumu praktycznego" w "ducha obiektywnego" i zwrócenia się ku "praktyce” - czyli pracy, działaniu społecznemu, bądź też komunikacji), a także w amerykańskim pragmatyzmie (C.S. Peirce). Z połączenia tych dwu nurtów filozoficznego namysłu wyrasta teoria racjonalności komunikacyjnej J. Habermasa, która jest też odpowiedzią na wyzwanie, jakim jest pluralizm światopoglądowy. Stanowisko Twardowskiego w kwestii niefilozoficznego charakteru zajmowania się „poglądami na świat i życie” przyczyniło się do tego, że polska myśl filozoficzna nie przebyła drogi wiodącej od Hegla, przez Wilhelma von Humbold ta, Charlesa Sandersa Peirce'a, Hansa-Georga Gadamera, do Jürgena Habermasa.

Słowa kluczowe: Kazimierz Twardowski, światopogląd, filozofii naukowa, krytycyzm, transcedentalizm, rozum praktyczny, Kant, Szkoła Lwowsko-Warszawska

Summary: Kazimierz Twardowski's View on the Philosophical Approach to "Views on the World and Life". A Short Comment on Practical Reason

The fate of "practical philosophy" in Poland was largely influenced

250 by the views of Kazimierz Twardowski. This one, who had great merits for Polish philosophy, disciple of F. Brentano, was, on the one hand, a great admirer of Immanuel Kant and, on the other hand, completely disavowed his concept of practical reason. The source of the admiration was that Kant deprived metaphysics (in its then and former understanding) of its right to have itself as a science, while he demanded that philosophical thinking should be moved to criticism. However, Twardowski seemed to completely overlook the fact that Kant's criticism cannot be detached from - the other side of it - Kant's transcendentalism. Admittedly, in a certain trend of the continuation of Kant's transcendentalism in German philosophy, as well as by its Polish creative followers, there was a "dogmatic swing in the clouds". However, this is not yet a sufficient reason to part with practical reason and agree with Twardowski, who claims that philosophy is not in charge of dealing with "views on the world and life". Such views, among other things, on matters which have been dealt with by "practical reason" for centuries, have contributed to the creation of a gap in Polish philosophy of thinking about the possibility of dealing with matters connected with the view on the world and life within philosophy. Such thought, on the other hand, was carried out in German philosophy (as a result of Hegel's transformation of "practical reason" into "objective spirit", and the turn to "practice" - which means turning to work, social activity, or communication), as well as in American 
Pogląd Kazimierza Twardowskiego na temat zajmowania się przez filozofię...

pragmatism (Charles Sanders Peirce). The theory of communicative rationality by Jürgen Habermas, which is also a response to the challenge of pluralism of world views, emerges from the combination of these two currents of philosophical reflection. Twardowski's stance on the non-philosophical nature of dealing with "views on the world and life" contributed to the fact that Polish philosophical thought did not follow the path leading from Hegel, through Wilhelm von Humboldt, Charles Sanders Peirce, Hans-Georg Gadamer to Jürgen Habermas.

Keywords: Kazimierz Twardowski, worldview, scientific philosophy, criticism, transcendentalism, practical reason, Kant, Lviv-Warsaw School 